\title{
PENGARUH PERMAINAN EDUKATIF FINGER PAINTING TERHADAP PERKEMBANGAN MOTORIK HALUS ANAK USIA PRASEKOLAH 4-5 TAHUN DI TK KUMARA STANA DESA MUNDUK
}

\author{
Kadek Dwi Sentana Putra ${ }^{1}$ \\ ${ }^{1}$ IHDN Singaraja \\ Correspondence author: dwisentana@gmail.com
}

(The Effect of Finger Painting Educational Game on the Development of PreSchoolers Age 4-5 Fine Motoric at Kumara Stana Kindergarten, Munduk Village)

\begin{abstract}
ABSTRAK
Pendahuluan: Anak usia prasekolah adalah mereka yang berusia 3-6 tahun. Anak merupakan dambaan setiap keluarga. Selain itu setiap keluarga juga mengharapkan anaknya kelak bertumbuh kembang secara optimal. Melukis dengan jari (finger painting) merupakan salah satu kegiatan teknik melukis dengan mengoleskan cat pada kertas basah menggunakan jari jemari yang dapat dilakukan anak untuk menuangkan imajinasinya melalui lukisan yang dibuat dengan jari jemari anak, dalam kegiatan ini dapat melatih motorik halus dan kreativitas yang dimiliki anak. Penelitian ini bertujuan untuk menganalisis pengaruh permainan edukatif finger painting terhadap perkembangan motorik halus anak usia prasekolah 4-5 tahun di TK Kumara Stana Desa Munduk. Metode: Penelitian ini menggunakan pra-eksperimental dengan rancangan one group pre-post test design. Besar sampel dalam penelitian ini 30 responden yang diambil menggunakan teknik purposive sampling. Hasil: Penelitian ini menggunakan uji pairedt-test didapatkan nilai dengan taraf signifikan $\mathrm{p}=0,05$ didapatkan ( $\mathrm{p}$ ) adalah 0,000 yang menunjukan bahwa $\mathrm{p}<0,05$ $(0,000<0,05)$, artinya $\mathrm{H}_{0}$ ditolak dan $\mathrm{H}_{\mathrm{a}}$ diterima. Simpulan: Disimpulkan bahwa ada pengaruh permainan edukatif finger painting terhadap perkembangan motorik halus anak usia prasekolah 4-5 tahun di TK Kumara Stana Desa Munduk.
\end{abstract}

Kata Kunci: permainan edukatif finger painting, perkembangan motorik halus

\begin{abstract}
Introduction: Preschool children are those aged 3-6 years. Children are the dream of every family. In addition, every family also hopes that their children will grow and develop optimally. Painting with fingers (finger painting) is one of the painting technique activities by applying paint to wet paper using fingers that children can do to pour their imagination through paintings made with children's fingers, in this activity it can train the child's fine motor skills and creativity. This study aimed to analyze the effect of finger painting educational games on the fine motoric development of preschool children aged 4-5 years in Kumara Stana Kindergarten, Munduk Village. Method: This study used a pre-experimental design with one group pre-post test design. The sample size in this study was 30 respondents who were taken using purposive sampling technique. Result: This study used the Paired-t-test, the value obtained with a significant level of $p=0.05$ was obtained $(p)$ was 0.000 , which indicates that $p<0.05(0.000<0.05)$, meaning that $\mathrm{HO}$ was rejected and $\mathrm{Ha}$ was accepted. Conclusion: It is concluded that there is an effect of finger painting educational games on the fine motoric development of preschool children aged 4-5 years in Kumara Stana Kindergarten, Munduk Village.
\end{abstract}

Keywords: finger painting educational game, fine motoric development

\section{PENDAHULUAN}

Anak usia prasekolah adalah mereka yang berusia 3-6 tahun. Anak merupakan dambaan setiap keluarga. Selain itu setiap keluarga juga mengharapkan anaknya kelak bertumbuh kembang secara optimal dapat dibanggakan serta berguna bagi nusa dan bangsa. Anak adalah individu yang unik, yang masih bergantung pada orang dewasa dalam memenuhi kebutuhan dasarnya (Soetjiningsih \& Gede Ranuh, 2013).
Tumbuh kembang merupakan manifestasi yang kompleks dari perubahan morfologi, biokimia, dan fisiologi yang terjadi sejak konsepsi sampai maturase/dewasa. Banyak orang menggunakan istilah "tumbuh" dan "kembang" secara sendirisendiri atau bahkan ditukar-tukar. Istilah tumbuh kembang sebenarnya mencakup dua peristiwa yang sifatnya berbeda, Tetapi saling berkaitan dan sulit dipisahkan yaitu partumbuhan dan perkembangan 
(Soetjiningsih \& Gede Ranuh, 2013).

Menurut Kementrian Pendidikan Nasional (Kemendiknas, 2010), mengatakan bahwa upaya pemerintah dalam hal mengatasi keterlambatan perkembangan pada anak adalah dengan cara memfasilitasi kegiatan pendidikan anak usia prasekolah yang dibuktikan pada Peraturan Pemerintah No.27/1990 tentang pendidikan prasekolah yaitu: Pendidikan prasekolah adalah pendidikan untuk membantu pertumbuhan dan perkembangan jasmani rohani anak didik di luar lingkungan keluarga sebelum memasuki pendidikan dasar yang diselenggarakan di jalur pendidikan luar sekolah. Bentuk satuan pendidikan prasekolah meliputi Taman KanakKanak, Kelompok Bermain, Penitipan Anak dan bentuk lain yang ditetapkan oleh menteri.

Berdasarkan hasil Survey Bavarian PreSchool Morbidity Survey (BPMS) pada anak prasekolah dari tahun 1997-2009 terjadi peningkatan keterlambatan motorik halus yang signifikan dari $4,07 \%$ menjadi $22,05 \%$ antara tahun 1997-2009. Menurut WHO (World Health Organization) $5-25 \%$ dari anak mengalami gangguan motorik halus. Gangguan motorik halus pada anak usia prasekolah diperkirakan 5-3\% dan sebanyak $60 \%$ dari kasus yang ditemukan terjadi secara spontan pada umur dibawah 5 tahun (Kementerian Republik Indonesia, 2012). Penelitian yang dilakukan oleh Vitamami (2013) menemukan bahwa motorik halus anak usia dini RA Babussalam Kelompok A2 masih belum tercapai secara optimal, ini dibuktikan dengan 9 anak dari 21 jumlah anak masih belum dapat mengambil benda dengan menggunakan 2 jari sehingga menyebabkan anak belum sempurna memegang pensil (Wahyu Nanda \& Indah, 2016).

Berdasarkan hasil studi pendahuluan pada tanggal 17 Januari 2019 di TK Kumara Stana Desa Munduk, peneliti melakukan wawancara dengan kepala sekolah dan diperoleh data yang menyebutkan bahwa jumlah siswa keseluruhan yaitu 43 siswa yang dibagi menjadi 2 kelas diantaranya kelas B1 dengan jumlah anak 21 siswa dan kelas B2 dengan jumlah 22 siswa. Menurut salah satu Guru TK Kumara Stana, banyak kegiatan yang dilakukan untuk meningkatkan motorik halus pada anak seperti: menggambar, menggunting dan mewarnai. Dengan menggunakan lembar Denver II terhadap 10 orang anak secara acak, didapatkan hasil bahwa 3 anak (30 \%) dikategorikan normal, karena anak mampu melakukan tugas memilih garis yang lebih panjang, menggambar orang 6 bagian dan mencontoh kotak. Kemudian dari 7 orang anak ada 5 orang anak $(50 \%)$ yang mengalami caution dan 2 orang anak (20\%) mengalami delayed, 5 orang anak $(50 \%)$ yang mengalami caution karena anak gagal dalam persentil $75 \%$ dan $90 \%$ seperti: anak hanya bisa menggambar orang 2 bagian dari 3 bagian, anak tidak bisa mencontoh + karena kedua garis yang berpotongan tidak mendekati titik tengah dan anak gagal dalam memilih garis yang lebih panjang. Sedangkan 2 orang anak (20\%) yang mengalami delayed karena anak gagal melakukan uji coba yang terletak disebelah kiri garis umur seperti; anak yang harusnya sudah bisa menggoyangkan ibu jarinya tetapi anak menggerakan semua jari-jarinya, dan anak gagal dalam menyusun menara dari 8 kubus.

Anak-anak yang mengalami keterlambatan dalam perkembangan motorik halusnya diberikan kegiatan dan permainan yang dilakukan secara bergantian dan berbeda-beda disetiap harinya seperti menggambar bebas, menggunting, meronce, menarik garis, dan bermain puzzle tetapi upaya tersebut belum berhasil untuk meningkatkan perkembangan motorik halus pada anak tersebut.

Permainan yang sifatnya mendidik biasa disebut dengan Alat Permainan Edukatif (APE) adalah alat permainan yang fungsinya dapat mengoptimalkan perkembangan anak, Hal ini tentunya disesuaikan dengan tingkat usia dan perkembangannya (Soetjiningsih \& Gede Ranuh, 2013). Permainan edukatif yang dapat merangsang perkembangan anak salah satunya adalah permainan melukis dengan jari (finger painting). Bermain melukis dengan jari mampu mengekspresikan imajinasi anak untuk membuat bentuk yang diinginkan (Rachmawati \& Kurniati, 2010).

Hal tersebut terkait dengan penelitian yang dilakukan oleh (Nina Astria, Made Sulastri, 2015) hasil analisis data menunjukkan bahwa terjadi peningkatan kemampuan motorik halus setelah penerapan metode bermain melalui kegiatan finger painting pada siklus I sebesar $65,93 \%$ yang berada pada kategori sedang, ternyata mengalami peningkatan pada siklus II menjadi $82,93 \%$ yang pada katagori tinggi. Jadi, peningkatan kemampuan membaca permulaan anak sebesar $17 \%$. Berdasarkan hasil penelitian tersebut dapat disimpulkan bahwa penerapan metode bermain melalui kegiatan finger painting dapat 
meningkatkan kemampuan motorik halus anak.

Permainan edukatif adalah suatu kegiatan yang sangat menyenangkan dan merupakan cara atau alat pendidikan yang bersifat mendidik. Permainan edukatif sangat bermanfaat untuk meningkatkan kemampuan berbahasa, berfikir serta bergaul dengan lingkungannya. Permainan edukatif juga bermanfaat untuk menguatkan dan menerampilkan anggota badan anak, mengembangkan kepribadian, mendekatkan hubungan antara pengasuh dengan anak, serta menyalurkan kegiatan anak. Prinsip dasar alat permainan edukatif adalah dapat meningkatkan dan mengembangkan kemampuan psikomotorik anak, sosial-emosional (seperti mempertajam perasaan, membentuk moralitas, spiritualitas, meningkatkan kepercayaan diri), serta kemampuan kecerdasan (Dian Adriana, 2017).

Melukis dengan jari (finger painting) merupakan salah satu kegiatan teknik melukis dengan mengoleskan cat pada kertas basah menggunakan jari jemari yang dapat dilakukan anak untuk menuangkan imajinasinya melalui lukisan yang dibuat dengan jari jemari anak, dalam kegiatan ini dapat melatih motorik halus dan kreativitas yang dimiliki anak (Yunita handra Yetri, 2011).

Anak usia prasekolah juga sudah lebih aktif, kreatif dan imajinatif. Menurut (Rachmawati \& Kurniati, 2010) kegiatan melukis dengan jari dapat meningkatkan kemampuan berpikir dan berbuat kreatif, serta mengembangkan kemampuan dalam mengungkapkan nilai-nilai estetika dengan menggambar karya-karya kreatif.

Menurut (Andri Setia Ningsih, 2015) dengan penelitian yang berjudul Identifikasi Perkembangan Keterampilan Motorik Halus Anak Dalam Berbagai Kegiatan Main Kelompok B dengan hasil penelitian yang menunjukkan bahwa perkembangan keterampilan motorik halus anak Kelompok B se-Gugus Parkit secara keseluruhan pada 8 kegiatan main yaitu menggunting, menempel, mewarnai, menganyam, meronce, membentuk, mengarsir, dan menyalin kata atau angka. Secara keseluruhan dapat dilihat dari 97 anak: (1) Kategori Mulai Berkembang sebesar (4.10\%); (2) Kategori Berkembang Sesuai Harapan sebesar (16.50\%); dan (3) Kategori Berkembang Sangat Baik sebesar (79.40\%).

Alat yang digunakan untuk mengumpulkan data pada peelitian ini berupa lembar observasi DDST II untuk mengukur perkembangan motorik halus responden. Lembar observasi tersebut berisi data demografi responden terdiri dari nama, responden, umur dan jenis kelamin.

\section{METODE PENELITIAN}

Penelitian ini menggunakan penelitian pre eksperimental, karena dalam penelitian ini memberikan perlakuan atau intervensi pada objek yang akan diteliti. Desain yang digunakan dalam penelitian ini yaitu One Group Pre-Test Dan PostTest, dimana objek yang akan diteliti sebelum diberikan perlakuan dilakukan pre-test terlebih dahulu dan setelah diberikan perlakuan atau intervensi akan dilakukan post-test (Nursalam 2015). Penelitian ini dilakukan di TK Kumara Stana Desa Munduk.

\section{HASIL PENELITIAN}

Sampel penelitian ini adalah anak dengan gangguan perkembangan motorik halus yang sudah memenuhi kriteria inklusi yang berjumlah 30 orang. Adapun karakteristik sampel penelitian ini adalah sebagai berikut:

Tabel 1. Karakteristik Subjek Penelitian Berdasarkan Usia

\begin{tabular}{lll}
\hline Jenis Kelamin & Jumlah & $(\%)$ \\
\hline Laki-Laki & 13 & 43,3 \\
Perempuan & 17 & 56,7 \\
\hline Total & $\mathbf{3 0}$ & $\mathbf{1 0 0}$ \\
\hline
\end{tabular}

Tabel 1 menunjukan bahwa nilai rata-rata usia responden adalah 4,57 dengan usia tertinggi 5 tahun dan usia terendah 4 tahun.

Tabel 2. Karakteristik Responden Berdasarkan Jenis Kelamin di TK Kumara Stana Desa Munduk

\begin{tabular}{ccccc}
\hline Variabel & Min & Maks & Mean & $(\mathrm{N})$ \\
\hline Usia & 4 & 5 & 4,57 & 30 \\
\hline
\end{tabular}

Tabel 2 menunjukkan bahwa bahwa dari 30 orang responden, sebagian besar berjenis kelamin perempuan yaitu sebanyak 17 orang $(56,7 \%)$ dan responden berjenis kelamin laki-laki sebanyak 13 orang $(43,3 \%)$. 
Tabel 3. Perkembangan Motorik Halus Anak Usia 4-5 Tahun di TK Kumara Stana Desa Munduk sebelum Diberikan Intervensi Permainan Finger Painting.

\begin{tabular}{lccccc}
\hline & $\mathrm{N}$ & Mean & Min & Max & SD \\
\hline $\begin{array}{l}\text { Pre- } \\
\text { Test }\end{array}$ & 30 & 43,87 & 14 & 70 & 19,009 \\
\hline
\end{tabular}

Tabel 3 bahwa dari 30 orang total responden yang menjadi subjek penelitian rata-rata (mean) skor perkembangan motorik halus sebelum pemberian permainan finger painting adalah 43,87 (caution), dengan standar deviation 19,009. Nilai kategori motorik halus terendah adalah 14 dan tertinggi 70 .

Tabel 4. Perkembangan Motorik Halus Anak Usia 4-5 Tahun di TK Kumara Stana Desa Munduk setelah Diberikan Intervensi Permainan Finger Painting.

\begin{tabular}{cccccc}
\hline & N & Mean & Min & Max & SD \\
\hline $\begin{array}{l}\text { Post } \\
\text { Test }\end{array}$ & 30 & 67,20 & 14 & 98 & 19,935 \\
\hline
\end{tabular}

Tabel 4 menunjukkan bahwa dari 30 orang total responden yang menjadi subjek penelitian rata-rata (mean) skor perkembangan motorik halus setelah pemberian permainan finger painting adalah 67,20 (Normal), dengan standar deviation 19,935. Nilai kategori motorik halus terendah adalah 14 dan tertinggi adalah 98 .

Tabel 5. Uji Normalitas Skewness

\begin{tabular}{cccc}
\hline & Skewness & SE & $\begin{array}{c}\text { Hasil } \\
\text { Bagi }\end{array}$ \\
\hline Pre Test & 0,396 & 0,427 & 0,928 \\
Post & 0,616 & 0,427 & 1,444 \\
Test & & & \\
\hline
\end{tabular}

Tabel 5 menunjukan bahwa hasil pembagian skewness dan standard error dari nilai pre tes dan post test keduanya kurang dari 2 dimana data yang berdistribusi normal didapat dari hasil bagi skewness dengan standard error harus $<2$ sehingga dapat disimpulkan bahwa kedua data di atas berdistribusi normal, karena data berdistribusi normal, maka uji yang digunakan yaitu uji paired t-test.
Tabel 6. Hasil Uji Pre dan Post Test dengan Menggunakan Uji Paired T-Test

\begin{tabular}{|c|c|c|c|c|c|}
\hline \multicolumn{6}{|c|}{ Paired Differences } \\
\hline & $\begin{array}{l}\text { Mean } \\
\text { \& SD }\end{array}$ & $\begin{array}{c}\text { Std. } \\
\text { Error }\end{array}$ & $\mathbf{t}$ & $\begin{array}{l}\text { D } \\
\text { f }\end{array}$ & $\mathbf{P}$ \\
\hline Paire & - & & & & \\
\hline $\mathrm{d} 1$ & 23.33 & & - & & \\
\hline Pre- & $3 \&$ & 11.819 & 10.8 & $\begin{array}{l}2 \\
0\end{array}$ & 0,000 \\
\hline Post & 11.81 & & 14 & & \\
\hline test & 9 & & & & \\
\hline
\end{tabular}

Tabel 7. Hasil Uji Pre dan Post Test dengan Menggunakan Uji Koefisien Kappa

\begin{tabular}{cccccc}
\hline & & \multicolumn{2}{c}{ Pre-Test } & \multicolumn{2}{c}{ Post-Test } \\
\cline { 3 - 6 } & $\mathrm{N}$ & Value & $\begin{array}{c}\text { Appr } \\
\text { ox } \\
\text { Sig }\end{array}$ & V & $\begin{array}{c}\text { Approx } \\
\text { Sig }\end{array}$ \\
\hline Pen & 30 & 1,000 & 0,000 & 1,000 & 0,000 \\
\hline $\begin{array}{l}\text { The } \\
\text { rap }\end{array}$ & 30 & 1,000 & 0,000 & 1,000 & 0,000 \\
\hline
\end{tabular}

Tabel 7 menunjukan bahwa hasil sig. (2-tailed) atau nilai $\mathrm{p}=0,000$ karena nilai $\mathrm{p}$ lebih kecil dari 0,05 $(\mathrm{p}<0,05)$ maka hipotesis nol $\left(\mathrm{H}_{0}\right)$ ditolak dan hipotesis alternatif $\left(\mathrm{H}_{\mathrm{a}}\right)$ diterima. Sehingga dapat disimpulkan bahwa terdapat pengaruh permainan edukatif finger painting terhadap perkembangan motorik halus anak usia prasekolah 4-5 tahun di TK Kumara Stana Desa Munduk.

\section{PEMBAHASAN}

Dilihat dari karakteristik responden berdasarkan usia, dari 30 responden rata-rata (mean) usia responden adalah 4,57 tahun. Dengan usia tertinggi 5 tahun dan usia terendah 4 tahun. Hal ini sejalan dengan penelitian yang dilakukan oleh (Lilis Maghfuroh \& Kiki Chayaning Putri, 2017) tentang pengaruh finger painting terhadap perkembangan motorik halus anak usia prasekolah di TK sartika 1 Sumurgenuk Kecamatan Babat Lamongan. Pada penelitian ini karakteristik responden mayoritas berusia 4 tahun yaitu sebanyak 9 orang $(41,7 \%)$ dan berusia 5 tahun yaitu sebanyak 15 orang $(58,3 \%)$.

Selain itu karakteristik responden berdasarkan jenis kelamin, dari 30 responden sebagian besar berjenis kelamin perempuan sebanyak 17 orang $(56,7 \%)$ dan laki-laki sebanyak 13 orang $(43,4 \%)$ Dalam hal ini jenis kelamin seseorang tidak berpengaruh pada perkembangan motorik halus yang dimilikinya. Anak dengan jenis kelamin lakilaki maupun perempuan pada masa ini mempunyai 
kesempatan untuk bermain apapun. Hal ini sejalan dengan penelitian yang dilakukan oleh Hendrawati, dkk (2014) tentang penerapan metode demosntrasi melalui kegiatan melukis dengan cara ikonvesional untuk meningkatkan keterampilan motorik halus anak. Pada penelitian ini karakteristik responden mayoritas berjenis kelamin perempuan yaitu sebanyak 24 oramg $(57,1 \%)$ dan berjenis kelamin laki-laki sebanyak 18 orang $(42,9 \%)$. Hasil penelitian diperoleh nilai minimal perkembangan motorik halus sebesar 14 poin dan nilai maksimal perkembangan motorik halus sebesar 70 poin.hasil penelitian menunjukan 30 anak usia 4-5 tahun di TK Kumara Stana Desa Munduk sebelum diberikan permainan finger painting yaitu berada pada kategori normal sebanyak 12 anak (40,0\%), kategori caution sebanyak 13 anak $(43,3 \%)$ dan 5 anak $(16,7 \%)$ berada pada kategori delayed. Rata-rata (mean) skor perkembangan motorik halus sebelum diberikan permainan finger painting adalah 43,87\%, dengan standar deviation 19,009. Penelitian yang dilakukan oleh (Febri Nuraini, 2015) disimpulkan bahwa kreativitas anak di RA Sunan Averrous Bogoran dapat ditingkatkan melalui kegiatan finger painting untuk memberikan ide gambar dan warna, melakukan pencampuran warna dan memodifikasi gambar, membuat karya dari ide anak sendiri dan menghasilkan karya yang berbeda. Anak-anak yang bermain dengan finger painting perkembangan motorik halusnya akan lebih optimal. Hasil penelitian didapatkan pada siklus 1 mencapai $64,95 \%$ setelah diberikan permainan finger painting pada siklus 1 meningkat menjadi 87,05\%.Perkembangan Motorik Halus Anak Usia 4-5 Tahun setelah diberikan Permainan Finger Painting

Setelah diberikan Permainan Finger Painting selama 3 minggu dalam 9 kali pertemuan pada anak usia 4-5 tahun di TK Kumara Stana Desa Munduk, hasil penelitian menunjukan hasil pengukuran perkembangan motorik halus responden setelah diberikan permainan finger painting adalah sebanyak 10 anak $(33,3 \%)$ masuk dalam kategori advance, 14 anak (46,7\%) masuk dalam kategori normal, 5 anak $(16,7 \%)$ masuk dalam kategori caution dan sebanyak 1 anak $(3,3 \%)$ masuk dalam kategori delayed. Rata-rata (mean) skor perkembangan motorik halus setelah diberikan Permainan finger painting adalah 67,20, dengan standar deviation 19,935. Hal ini juga sesuai dengan penelitian yang dilakukan oleh
(Nina Astria \& Made Sulastri, 2015) menyatakan bahwa kegiatan finger painting adalah cara menyampaikan kegiatan pembelajaran yang tepat kepada anak pada saat berlangsungnya proses pembelajaran sehingga menghasilkan pemahaman yang maksimal. Anak akan lebih memaknai pembelajaran apabila dilakukan dengan cara bermain.

Hasil uji analisis data dengan menggunakan uji paired sample t-test didapatkan bahwa p-value $0,000(p<0,005)$. Hasil ini menandakan bahwa $\mathrm{H}_{0}$ dalam penelitian ini ditolak dan $\mathrm{H}_{\mathrm{a}}$ diterima yang berarti terdapat pengaruh permainan edukatif finger painting terhadap perkembangan motorik halus anak usia prasekolah 4-5 tahun di TK Kumara Stana Desa Munduk. Melihat pengaruh permainan edukatif finger painting terhadap perkembangan motorik halus anak usia prasekolah 4-5 tahun di TK Kumara Stana Desa Munduk dengan cara membandingkan hasil rata-rata skor perkembangan motorik halus sebelum dan setelah intervensi permainan finger painting diberikan. Hasil rata-rata (mean) perkembangan motorik halus sebelum diberikan intervensi permainan finger painting adalah 43,87 dan setelah diberikan intervensi permainan finger painting menjadi 67,20. Penelitian ini membuktikan adanya pengaruh permainan edukatif finger painting terhadap kemampuan motorik halus anak usia prasekolah 4-5 tahun di TK Kumara Stana Desa Munduk. Hal ini sejalan dengan penelitian yang dilakukan oleh (Nunung Nurjanah, 2017) yang berjudul Pengaruh Finger Painting terhadap Perkembangan Motorik Halus Anak Usia Prasekolah di TK at-Taqwa menunjukan hampir seluruhnya anak memiliki perkembangan motorik halus setelah diberikan finger painting, dengan nilai $\mathrm{p}=0,001$ dimana $\mathrm{p}<$ 0,05 maka Ha diterima artinya ada pengaruh finger painting terhadap perkembangan motorik halus anak usia prasekolah di TK At-Taqwa.

\section{SIMPULAN DAN SARAN Simpulan}

Karakteristik responden berdasarkan jenis kelamin dari 30 responden, dapat disimpulkan sebagian besar berjenis kelamin perempuan sebanyak 17 orang $(56,7 \%)$ dan sebagian kecil berjenis kelamin laki-laki sebanyak 13 orang $(43,4 \%)$. Dari 30 anak didapatkan hasil pre-test nilai terendah 14 dan nilai tertinggi 70 . Rata-rata (mean) skor perkembangan motorik halus anak usia 4-5 tahun di TK Kumara Stana Desa Munduk 
sebelum pemberian permainan finger painting adalah 43,87, standar deviation 19,009 dan standar error mean 3,471. Rata-rata (mean) skor perkembangan motorik halus setelah diberikan intervensi permainan Finger painting 67,20, standar deviaton 19,935 dan standar error mean 3,640. Hasil uji analisis data dengan menggunakan uji paired sample t-test didapatkan bahwa p-value 0,000 (p<0,005). Hasil ini menandakan bahwa $\mathrm{H}_{0}$ dalam penelitian ini ditolak dan $\mathrm{H}_{\mathrm{a}}$ diterima yang berarti terdapat pengaruh permainan edukatif finger painting terhadap perkembangan motorik halus anak usia prasekolah 4-5 tahun di TK Kumara Stana Desa Munduk.

\section{Saran}

Hasil penelitian ini diharapkan dapat digunakan untuk mengembangkan materi tentang tumbuh kembang anak yaitu perkembangan motorik halus dalam Pendidikan keperawatan dan menambah referensi perpustakaan.

Bagi tempat penelitian di TK Kumara Stana Desa Munduk, hasil penelitian ini diharapkan dapat menjadi pedoman dalam pengembngan aspek motorik halus pada anak dan dapat memberikan Permainan Edukatif Finger Painting pada anak-anak sebagai salah satu media yang dapat mengoptimalkan perkembangan motorik halus pada anak-anak didik di TK Kumara Stana Desa Munduk.

Hasil penelitian ini diharapkan dapat digunakan sebagai data dalam melakukan penelitin selanjutnya dan mampu memberikan pedoman atau bahan pertimbangan untuk mengembangkan penelitian dibidang keperawatan yang berkaitan dengan perkembangan motorik halus pada anak dengan memperhatikan alat ukur dan aspek-aspek lainnya.

\section{DAFTAR PUSTAKA}

Andri Setia Ningsih. (2015). Identifikasi Perkembangan Keterampilan Motorik Halus Anak Dalam berbagai Kegiatan Main Kelompok B.

Dian Adriana. (2017). Tumbuh Kembang \& Terapi Bermain Pada Anak (Edisi Kedu). Jakarta: Salemba Medika.

Febri Nuraini. (2015). Upaya Meningkatkan Kreativitas Melalui Finger Painting Pada Anak Di RA Sunan Averrous Bogoran Bantul.
Lilis Maghfuroh, \& Kiki Chayaning Putri. (2017). Pengaruh Finger Painting Terhadap Perkembangan Motorik Halus Anak Usia Prasekolah Di TK Sartika I Sumurgenuk Kecamatan Babat Lamongan, Volume 10.

Nina Astria, Made Sulastri, M. M. (2015). PENERAPAN METODE BERMAIN MELALUI KEGIATAN FINGER PAINTING UNTUK MENINGKATKAN KEMAMPUAN MOTORIK HALUS, Volume 3 No.

Nina Astria, \& Made Sulastri, M. M. (2015). Penerapan Metode Bermain Melalui Kegiatan Finger Painting Untuk Meningkatkan Kemampuan Motorik Halus, Volume 3.

Nunung Nurjanah, C. S. \& B. D. A. P. (2017). Pengaruh Finger Painting Terhadap Perkembangan motorik Halus Anak Prasekolah Di TK At-Taqwa, Volume 5.

Rachmawati \& Kurniati. (2010). Strategi Pengembangan Kreativitas Pada Anak (Edisi 1). Jakarta Kencana.

Soetjiningsih \& Gede Ranuh. (2013). Tumbuh Kembang Anak (Edisi 2). Jakarta: EGC.

Wahyu Nanda \& Indah. (2016). Perkembangan motorik halus anak usia 3-4 tahun di kelompok bermain cendekia kids school madiun dan implikasinya pada layanan konseling, 03, 1-11.

Yunita handra Yetri. (2011). Sittliche Grenzen des Handelns. Krankenpflege Journal, 3(11), 560561. 